\title{
Production of Biodiesel from Waste Canola Cooking Oil in Pakistan
}

\author{
Zaibunnisa Hussain, Saeed Ahmad Nagra, and Mehwish Jamil
}

\begin{abstract}
Biodiesel can be manufactured from specifically grown crops that would otherwise serve no purpose. However, some types of biodiesel raise certain ethical issues because they are made from crops which are used as a food source. Alternatively, biodiesel can be prepared from waste oil which has already been used in the manufacture of a product, normally food, such as crisps or from restaurants that use oil in fryers. Edible vegetable oils such as canola, soybean and corn have been used for biodiesel production and found to be a good diesel substitute but commercialization of biodiesel production from edible vegetable oil is expensive due to the high cost of oil. A promising alternative to edible vegetable oil is waste (canola) cooking oil. Biodiesel production by a transesterification reaction can be catalysed with alkali, acid or enzyme, but the latter is more time consuming and costly. The present study investigated biodiesel production from waste (canola) cooking oil in a two-step acid base catalysed process using ferric sulphate in step 1 and potassium hydroxide in step 2. Methanol was used as solvent for the catalysed process. Characterization of waste (canola) cooking oil was expressed in terms of acid value and saponification value. Conversion experiments were performed at different operating conditions including four methanol to oil ratios ranging from 3:1 to 6:1, four different catalyst amounts of $0.5,1,1.5$ and 2 (wt. \%) at reaction time of one hour and temperature of $100^{\circ} \mathrm{C}$. Analysis of the product was performed using titration method, infra-red spectroscopy and Gas Chromatography Flame Ionization Detector (GC/FID). Results indicated that increase in methanol to oil ratio and wt. \% of catalyst increased the yield of biodiesel produced.
\end{abstract}

Index Terms-Biodiesel, edible oil, canola, transesterification, GC/FID.

\section{INTRODUCTION}

Diesel, a fuel derived from petroleum, is used to power diesel engines by combustion of this fuel using heat produced when air is compressed. Due to the widespread availability and low cost of petroleum diesel fuel, vegetable oil-based fuels gained little attention, except in times of high oil prices and shortages. Unfortunately, the newer diesel engine designs could not run on traditional vegetable oils, due to the much higher viscosity of vegetable oil compared to petroleum diesel fuel. A breakthrough was needed to lower the viscosity of vegetable oils to a point where they could be burned properly in the diesel engine. Many methods have been proposed to perform this task, including pyrolysis, blending with solvents and even emulsifying the

Manuscript received November 29, 2014; revised March 20, 2015.

Zaibunnisa Hussain and Mehwish Jamil are with the Institute of Chemistry, University of the Punjab, Lahore, Pakistan 54590 (email: drzh1972@hotmail.com, meh.jamil@hotmail.com).

Saeed Ahmad Nagra is with the Department of Food Science \& Human Nutrition, UVAS, Lahore, Pakistan 54000 (email: dr.sanagra@gmail.com). fuel with water or alcohols, none of which have provided a suitable solution.

Biodiesel is a mono-alkyl ester of long chain fatty acids produced from renewable feed stocks. It is a nontoxic,biodegradable, relatively less inflammable fuel compared to the normal diesel and has considerably lower emissions than petroleum-based diesel [1].Thebenefits of biodiesel as diesel fuel are liquid nature portability, readily available, renewability, higher combustion efficiency, lower sulfur and aromatic content [2], [3], higher cetane number and higher biodegradability[4]-[6]. The main advantages of biodiesel include domestic origin, reducing the dependency on imported petroleum, biodegradability, high flash point and inherent lubricity in the neat form [3].

Biodiesel can be made from renewable oilseed crops such as soybean, rapeseed, sunflower and from waste cooking oil. It is safe to handle and transport due to its high flash point as compared to petroleum diesel fuel. Biodiesel can be used alone or mixed in any ratio with petroleum diesel fuel. The most common blend is a mix of $20 \%$ biodiesel with $80 \%$ petroleum diesel, or B20 under recent scientific investigations. However, in Europe the current regulation predicts a maximum $5.75 \%$ biodiesel. Biodiesel contains $11 \%$ oxygen by weight and contains no sulfur. The use of biodiesel can extend the life of diesel engines because it is more lubricating than petroleum diesel fuel.

The higher heating values (HHVs) ofbiodiesels are relatively high $(39-41 \mathrm{MJ} / \mathrm{kg})$. Due to combustion ofbiodiesel the quantity of unburned hydrocarbon (HC) is reduced to $90 \%$ and that of polycyclic aromatic $\mathrm{HC}$ is reduced to $75 \%-90 \%$ (PAHs). It also provides reductions in particulates and carbon monoxide compared to petroleum diesel fuel.

Due to the use of biodiesel, $\mathrm{N}_{2} \mathrm{O}$ is reduced because biodiesel contains little nitrogen, as compared with petro diesel. Net contribution of carbon dioxide from biomass combustion is small [7]. Reductions in net carbon dioxide emissions are estimated at 77-104 g/MJ of diesel displaced by biodiesel [8].

Considerable efforts have been made to develop vegetable oil derivatives which approximate the properties and performance of hydrocarbon based diesel fuels. The problem with substituting triglycerides for diesel fuel is mostly associated with high viscosity, low volatility and polyunsaturated characters. The transesterification reaction is the basis for the production of modern biodiesel otherwise termed fatty acid methyl esters. Transesterification is the reaction of a fat or oil with an alcohol to form esters and glycerol. A catalyst is usually used to improve the reaction rate and yield. Excess alcohol is used to shift the equilibrium towards the product because of the reversible 
nature of reaction [9], [10]. For this purpose primary and secondary monohybrid aliphatic alcohols, having 1-8 carbon atoms, are used [11]-[13].The process of transesterification converts vegetable oil into three smaller molecules which are much less viscous and easy to burn in a diesel engine.

In the present work waste canola cooking oil was used in a two-step acid base catalysedprocess using ferric sulphate (step 1) and potassium hydroxide (step 2) to produce biodiesel. Analysis was carried out using GC/FID (Model KonikHRGC 4000B) and FTIR (Model IR Prestige 21) spectrometer.

\section{MATERIALS AND METHODS}

Waste canola cooking oil collected from household kitchen was used for the production of biodiesel by transesterification. Analytical grade potassium hydroxide flakes, methanol, ethanol, ferric sulphate, phenolphthalein were purchased from Merck, UK. All experiments for the transesterification reaction using ferric sulphate were performed in a250ml round bottom flask. A water cooled condenser, burette, pipettes and beakers were also required and the reaction was carried out under controlled temperature using a hot plate (Utech 0871710, UK) and magnetic stirrer. All samples were analysed using Fourier Transform Infrared Spectrophotometer (FTIR) and Gas Chromatography Flame Ionization Detector (GC/FID).

\section{A. Characterization of Waste Cooking Oil}

The quality of oil was expressed in terms of physiochemical properties e.g. acid value and saponification value. The saponification value of waste canola oil was 152 $\mathrm{mg} \mathrm{KOH} / \mathrm{g}$ and acid value was $0.64 \mathrm{mg} \mathrm{KOH} / \mathrm{g}$.

\section{B. Pretreatment}

The oil was initially filtered to remove any undissolved or suspended impurities and then heated at $105^{\circ} \mathrm{C}$ for one hour to remove excess water after which, determination of acid value and saponification value was carried out.

\section{Determination of Acid Value}

A known amount of waste cooking oil was taken in a titration flask, to which $40-50 \mathrm{ml}$ of ethanol was added. The mixture may require heating to allow for dissolution of the oil. A few drops of phenolphthalein were added, and the solution titrated against $0.1 \mathrm{~N}$ alc. $\mathrm{KOH}$ until the solution remained faintly pink after agitation for $30 \mathrm{~s}$. The volume of alc. $\mathrm{KOH}$ used was noted to calculate the acid value.

\section{Determination of Saponification Value}

A known amount of waste cooking oil was taken in an iodine flask to which $40 \mathrm{ml}$ of alc. $\mathrm{KOH}$ was added. A condenser was then attached to the iodine flask and the reaction mixture refluxed for 40 mins by heating at constant temperature. A blank was also prepared by refluxing $40 \mathrm{ml}$ of ethanol for 40 mins at constant temperature to obtain the mean value of titration. After refluxing, both blank and sample solutions were cooled immediately and phenolphthalein added. Both solutions were titrated against $0.1 \mathrm{~N} \mathrm{HCl}$ until the pink color disappeared.

\section{E. Ferric Sulphate Catalyzed Process (Two-Step)}

This process was carried out in two steps. Thefirst step involved esterification using ferric sulphate while the second step involved alkali transesterification using $\mathrm{KOH}$. The conversion experiments were performed at different operating conditions including four methanol to oil ratios ranging from 3:1 - 6:1 and four different catalyst amounts of $0.5,1,1.5,2$ (wt.\%). The reaction temperature was kept constant at $100^{\circ} \mathrm{C}$.

Step 1: $20 \mathrm{ml}$ of sample was taken in a $250 \mathrm{ml}$ roundbottom flask to which $60 \mathrm{ml}$ methanol and $0.5 \mathrm{wt} \%$ ferric sulphate was added. The mixture was heated to $100^{\circ} \mathrm{C}$ for 60 mins at atmospheric pressure. The reaction mixture was then poured into a separating funnel. Excess alcohol containing impurities was removed and the catalyst, alongwith the ester oil phase, settled to the bottom. The ferric sulphate acted as a heterogeneous acid catalyst and had very low solubility in the oil.

Step 2: After removal of the catalyst, the lower layer was collected for further processing. The product of step 1 was preheated to $100^{\circ} \mathrm{C}$ in a flask. Meanwhile, $0.22 \mathrm{~g}$ of $\mathrm{KOH}$ was dissolved in $15 \mathrm{ml}$ methanol and poured into the flask. The mixture was heated and stirred for $60 \mathrm{~min}$ after which the reaction mixture was allowed to separate forming two layers. The lower layer, which contained impurities and glycerol, was drawn off. The ester remained in the upper layer.

\section{RESUlTS AND DISCUSSION}

Step 1 was performed to convert free fatty acids in the waste cooking oil to methyl esters. The acid value of each sample after reaction provides an indication of this conversion in the form of esterification. Fig. 1(a)-Fig. 1(d) indicate that acid value decreases with increase in methanol to oil ratio and catalyst amount. Hence, the amount of free fatty acids is decreasing constantly. This in turn will increase the amount of ester formation. Therefore, an increase in methanol to oil ratio and catalyst amount increases the yield of biodiesel produced. In this case the optimum yield was obtained at methanol to oil ratio of $6: 1$ using catalyst (2 wt \%).

\section{A. Infrared Spectroscopy}

In order to determine the presence of esters in the biodiesel product, it was necessary to analyze the samples for specific peaks using FTIR. The results obtained are illustrated in Fig. 2(a) and Fig. 2(b). Each figure shows a prominent ester peak at $1745 \mathrm{~cm}^{-1}$. This peak corresponds to the esters of palmitic acid, stearic acid, oleic acid, linolinic acid and $\alpha$ - linoleic acid.

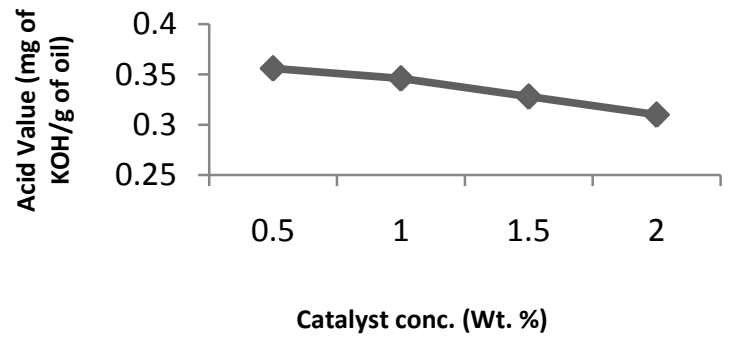

Fig. 1(a). Methanol to oil concentration (3:1). 


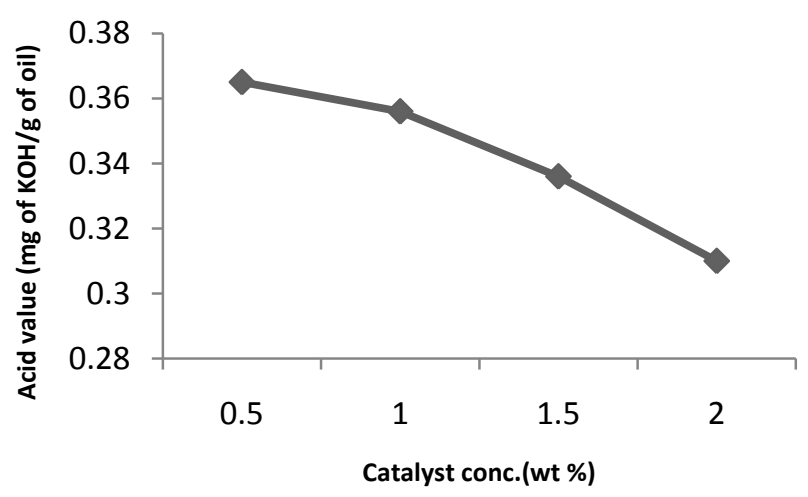

Fig. 1(b). Methanol to oil concentration (4:1).

This technique was carried out at Auriga Pvt, Lahore. The spectrum obtained from this analysis showed different peaks representing the different esters (Fig. 3). The analysis of samples was performed under the following GC/FID conditions: injection volume $1.5 \mu \mathrm{L}$, injection mode split, temperature $300^{\circ} \mathrm{C}$, initial temperature $190^{\circ} \mathrm{C}$, carrier gas $\mathrm{N}_{2}$ /air, column name TRBI, serial no. P2076697, film thickness $0.10 \mu$, column length $25 \mathrm{~m}$, inner diameter $0.25 \mathrm{~mm}$, detector FID. Standard peaks were relevant tothe following esters (Table I): cis-9-oleic methyl ester, methyl archidate, methyl behenate, methyl eicosenoate, methyl erucate (cis -13-docosen), methyl lignocerate, methyl linoleate, methyl linolenate, methyl myristate, methyl palmitate and methyl stearate.

TABLE I: ESTERS IN BIODIESEL PRODUCT (6:1, 2 WT\%)

\begin{tabular}{ccccc}
\hline Peaks & $\begin{array}{c}\text { Retention } \\
\text { time }\end{array}$ & Area & Area (\%) & Height \\
\hline $\begin{array}{c}\text { Methyl } \\
\text { palmitate }\end{array}$ & 3.666 & 4957 & 0.0170 & 1334 \\
$\begin{array}{c}\text { Methyl } \\
\text { stearate }\end{array}$ & 3.853 & 5132 & 0.0176 & 1695 \\
$\begin{array}{c}\text { Methyl } \\
\text { linoleate }\end{array}$ & 4.026 & 3322 & 0.1140 & 6489 \\
$\begin{array}{c}\text { Methyl } \\
\text { linolenate }\end{array}$ & 4.544 & 3003 & 0.130 & 9104 \\
$\begin{array}{c}\text { Oleic methyl } \\
\text { ester }\end{array}$ & 5.879 & 4019 & 0.0138 & 786 \\
\hline
\end{tabular}

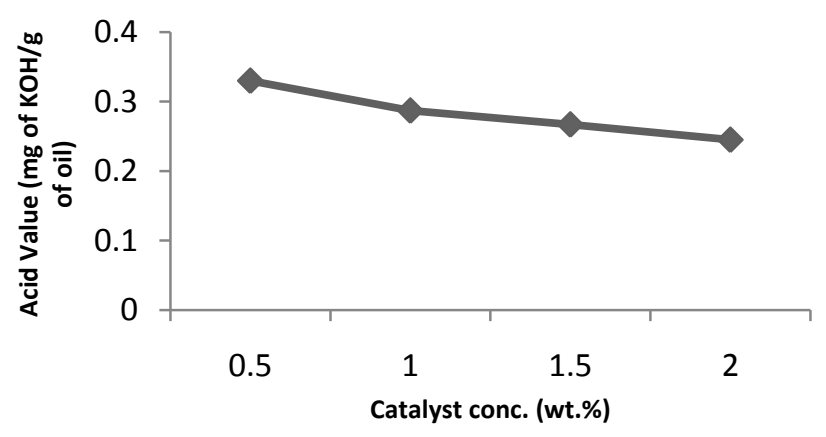

Fig. 1(c). Methanol to oil concentration (5:1).

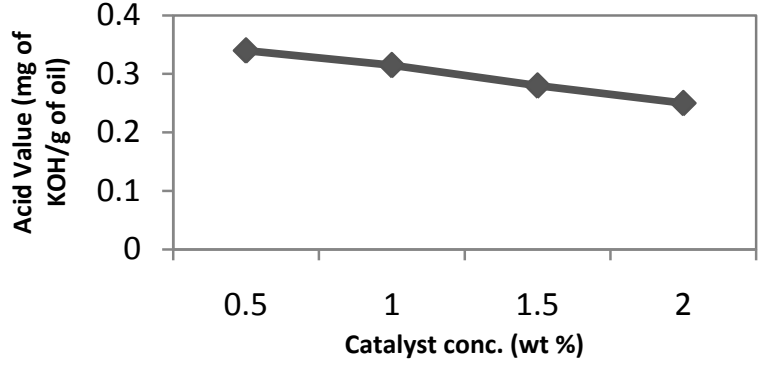

Fig. 1(d). Methanol to oil concentration (6:1).

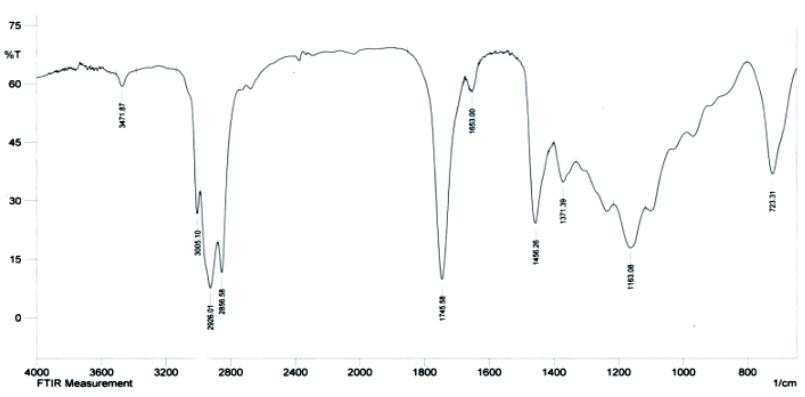

Fig. 2(a). Waste canola cooking oil.

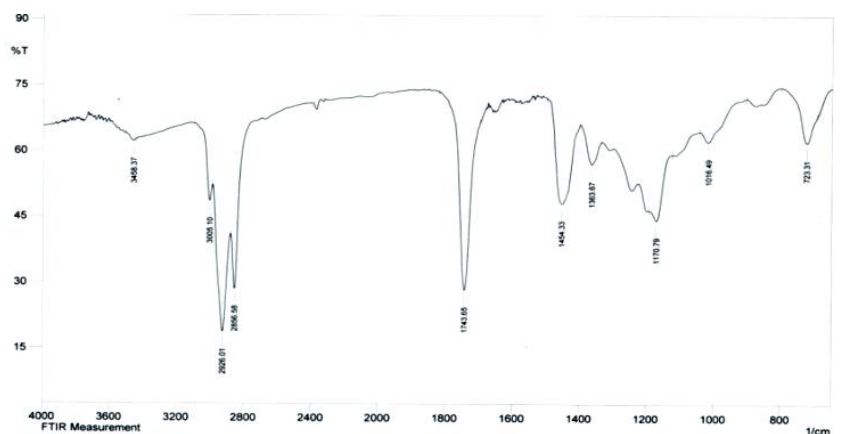

Fig. 2(b). Biodiesel product.

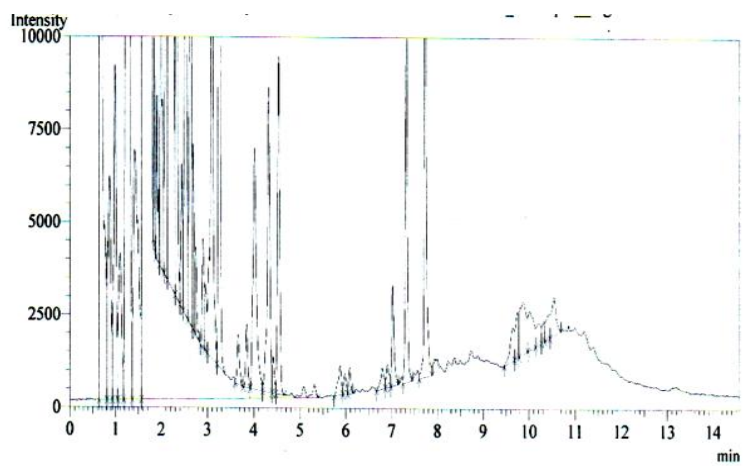

Fig. 3. Biodiesel product $(6: 1,2 \mathrm{wt} \%)$.

The maximum biodiesel yield for waste (canola) cooking oil using ferric sulphate as catalyst at a reaction time of 1 hour and reaction temperature of $100^{\circ} \mathrm{C}$ was obtained when the molar ratio of methanol to oil was $6: 1$ and catalyst (2 $\mathrm{wt} \%$ ). The acid value determined for this condition was $0.265 \mathrm{mg}$ of $\mathrm{KOH} / \mathrm{g}$ of oil. Ferric sulphate was shown to have good catalytic activity in the methanolysis of the free fatty acids of waste canola cooking oil. 


\section{ACKNOWLEDGMENTS}

The authors are grateful to $\mathrm{M} / \mathrm{s}$ Auriga Pvt, Lahore, Pakistan for their technical assistance during GC/FID sample analysis.

\section{REFERENCES}

[1] B. N. A. Barktay, "Energy potential of biodiesel generated from waste cooking oil: An environmental approach," Energ Source Part B, vol. 13, pp. 63-71, 2007.

[2] F. Ma and M. A. Hanna, "Biodiesel production: A review," Bioresource Technol, vol. 70, pp. 1-15, 1999.

[3] G. Knothe, C. A. Sharp, and T. W. Ryan, "Exhaust emissions ofbiodiesel, petrodiesel, neat methyl esters, and alkanes in a new technology engine," Energ Fuel, vol. 20, pp. 403-408, 2006.

[4] S. M. Mudge and G. Pereira, "Stimulating the biodegradation of crude oil with biodiesel preliminary results," Spill SciTechnol B, vol. 5, pp. 353-355, 1999.

[5] H. K. Speidel, R. L. Lightner, and I. Ahmed, "Biodegradability of new engineered fuels compared to conventional petroleum fuels and alternative fuels in current use," Appl Biochem Biotech, vol. 84, pp. 879-897, 2000

[6] Y. Zhang, M. A. Dub, D. D. McLean, and M. Kates, "Biodiesel production from waste cooking oil: Economic assessment and sensitivity analysis," Bioresource Technol, vol. 90, pp. 229-240, 2003.

[7] C. Carraretto, A. Macor, A. Mirandola, A. Stoppato, and S. Tonon, "Biodiesel as alternative fuel: experimental analysis and energetic evaluations," Energy, vol. 29, pp. 2195-2211, 2004

[8] R. R. Tan, A. B. Culaba, and M. R. I. Purvis, "Carbon balance implications of coconut biodiesel utilization in the Philippine automotive transport sector," Biomass Bioenerg, vol. 26, pp. 579-585, 2004.

[9] A. W. Schwab, G. J. Dykstra, E. Selke, S. C. Sorenson, and E. H. Pryde, "Diesel fuel from thermal decomposition of soybean oil," JAOCS, vol. 65, pp. 1781-1786, 1988.

[10] H. Noureddini and D. Zhu, "Kinetics of transesterification of soybean oil," JAOCS, vol. 74, pp. 1457-1463, 1997.

[11] F. J. Sprules and D. Price, "Production of fatty esters," U.S. Patent 2, 24943661950 .
[12] R. Sridharan and I. M. Mathai, "Transesterification reactions," $J$ SciInd Res, vol. 33, pp. 178-87, 1974.

[13] H. J. Kim, B. S. Kang, M. J. Kim, Y. M. Park, D. K. Kim, J. S. Lee, and K. Y. Lee, "Transesterification of vegetable oil to biodiesel using heterogeneous base catalyst," Catal Today, vol. 93, pp. 315-320, 2004

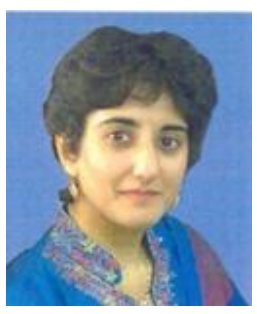

Zaibunnisa Hussain was born in Glasgow, Scotland (UK) and graduated from the University of Glasgow with BSc (Hons) Chemistry. In 1999 she was awarded her $\mathrm{PhD}$ from Brunel University, London (UK) and postdoctoral research fellowship in the field of environmental and industrialchemistry.

She has worked in the UK, Canada and Pakistan with invarious posts including business development coordinator, environmental consultant (as part of the technical working group for the UN) and foreign faculty professor. Currently she is serving at the Institute of Chemistry, University of the Punjab, Lahore, Pakistan. She has numerous publications to her name and is author of two books. Her current research interests include waste to energy generation.

Dr. Hussain is a member of both the Royal Society of Chemistry and American Chemical Society.

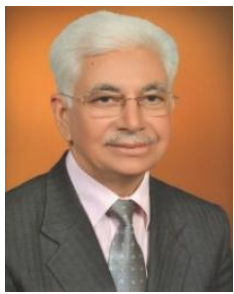

Saeed Ahmad Nagra was born in Faisalabad, Pakistan and obtained his MSc in chemistry from Quaid-i-Azam University, Islamabad and $\mathrm{PhD}$ in Nutrition from the University of Agriculture, Faisalabad, Pakistan. He was awarded DAAD postdoctoral fellowship for Stuttgart, Germany in 1997.

He has more than 40 years experience in teaching and research, and was appointed as the director of Institute of Chemistry, University of the Punjab, Lahore, Pakistan during 2008-2011. He has more than 100 publications to his credit and is the author of eight books. Currently he is serving as a professor of human nutrition at UVAS, Lahore, Pakistan. His current research interests include nutrition surveillance, utilization of food wastage and infant nutrition.

Prof. Nagra is a fellow of the Chemical Society of Pakistan, a fellow of the Pakistan Institute of Chemists and a fellow of the Pakistan Academy of Medical Sciences. 